\title{
Self - Isolation of Albania and the First Steps Toward Opening to the West
}

\author{
Alida Avdullari \\ University of Tirana / Faculty of Philology and History, \\ avdullarialida@yahoo.com \\ Doi:10.5901/ajis.2014.v3n3p82
}

The years 80 s are important for Albanian diplomacy, because the historical documents of the period observed variation between pre-self-isolation and steps back towards establishing relations with the West. Was the Albanian foreign policy in the ' 80 , a fulfilled diplomacy, after 1985, Enver Hoxha testament whereby it was cornered the general foreign politics? These principles were a mixture of the universal principles of the UN Charter, the principles and the special interests that had Tirana regime in the late twentieth century. The principles established by Enver Hoxha were in the political, economic, cultural and security ${ }^{1}$.

At he political level, the Albanian government will refrain: the principles of respect for independence, national sovereignty and territorial integrity, non-interference in internal affairs, cooperation on the basis of mutual interest and weakness. ${ }^{2}$ In the normal development there was free economic support and international trade while respecting equality, mutual benefits and convenience. ${ }^{3}$ Albanian state, under the constitution of 1976 on the principles refused aid, loans and credits from abroad. Although in principle the policy of economic cooperation with the outside of Albania was normal, in practice it did not bring any result. ${ }^{4}$ During this period they tried strongly from the ruling party, cultural exchanges. With most of the countries cultural activities were most frequent.

After the death of communist leader E.Hoxha, Alia took his place. Analysis and his vision on international affairs failed in the ninth Congress of the PLA held in November 1986 it did not represent new elements, in order to disclose the place of self-isolation. This platform presented basic principles of the Albanian state positions, for the last period of communism..$^{5}$ In this Congress, it was stated that: " He knew both friends and enemies of his country. He had attacked U.S. policy new global meetings between the two superpowers and making oath that there could be no reconciliation socialist Albania and two superpowers."6 Alia echoed Greek-Serbian thesis, which contained the view that : the Balkan should be for the people of the Balkans. In this context, the policy with neighbors took considerate place during his rule. Communist leader stressed that: the development of good neighborly relations would be a foreign policy priority of the People's Socialist Republic of Albania. ${ }^{7}$

Albanian government began to take part in round tables, held between representatives of the governments of the Balkan countries. Thus, in February 1988, the Albanian delegation took part for the first time at the meeting of Ministers of Foreign Affairs in Belgrade Balkan states. Political commentators praised this fact as evidence of substantial changes in the foreign policy of Albania. Reis Malile former minister of foreign affairs, who headed the delegation was defended with the assertion: "It is not we who change, it is the others who change."8

Albania was determined as: a place that would cut future meetings of this level in January of 1989. Albanian government it self praised this as a very positive event. Albanian Radio and Television Newspapers and made too echo this issue. ${ }^{9}$ This was a big step forward for Albania, since it was the first time in the history of the communist regime, which expected a meeting of such a level. With the establishment of these contacts in the diplomatic field, Albania can not be called isolated. However, this association was curtailed and realized within strictly defined limits. Albanian society was still closed. The instinct of self-defense of new phenomena, coming from the Soviet Union and the socialist countries of East Central Europe watched. ${ }^{10}$

\footnotetext{
${ }^{1}$ Bashkurti, Lisen.(2004). Self-Isolation diplomacy, Tirana, GEER, pg.583

2 The Central Archive, The Albanian Republic, Fond 14, Year 1988, File 4 , pg 7

3 Same place, pg. 8

${ }^{4}$ Bashkurti, Lisen. (2004). Self-Isolation diplomacy, Tirana, GEER, pg.584

${ }^{5}$ Dervishi, Kastriot .(2006). The history of the Albanian state 1912-2005, Tirana ,55, pg.771-772

${ }^{6}$ Same place

${ }^{7}$ Bashkurti, Lisen.(2004). Self-Isolation diplomacy, Tirana, GEER, pg.676

8 Smirnova, Nina.( 2004). The history of Albania during 20 Cent . Tirana, Ideart, pg.417

${ }^{9}$ AQSH, Fond 14, File 37, Year 1988, pg. 17

${ }^{10}$ Smirnova, Nina.( 2004). The history of Albania during 20 Cent .Tirana, Ideart, pg.410
} 
Recent developments in the Balkans, but also important events that occurred in the years '89-Eastern European countries, such as Czech Republic, Bulgaria, Hungary where mass demonstrations led to the liquidation of communism and warned his end in Albania. ${ }^{11}$ The dire economic situation in the late 80 s and early 90s, Alia forced to undertake some reforms, which affected and foreign policy. Albania came with a new idea for international relations. The biannual experience was collected as a result of active participation in Balkan cooperation made to understand the necessity of government involvement in European processes. In the January plenum of the Central Committee of APL, foreign policy was defined as task expansion of bilateral relations with its neighbors, as well as establishing links with other countries. It was followed by the principle: 'to each state which answers with friendship, friendship will be proposed by us as well .' Withdrawal from the ideological point of view of foreign policy made it possible to take another step and multilateral cooperation and radically revised attitude to relations with the USSR and the USA.

In April 1990, Alia said bluntly: Albania's interest for the creation of the European Security System; in collaboration with the European community, and that in light of new approaches to the changes that have occurred in the European continent, was put on the agenda the problem of establishing relations with the U.S. and the Soviet Union. ${ }^{12}$

In this spirit, the liberalization of Albanian foreign policy was conducted to establish diplomatic relations with the Federal Republic of Germany. The long road of negotiations had begun in fact, in 1980. The main obstacle in establishing reparations was the Second World War. Albania demanded that the Federal Republic of Germany to pay war damages to Albania. Messages coming from Tirana, in the years 1979-1980, Bonn answered; they were willing to enter into negotiations for the establishment of diplomatic relations, but without setting preconditions. German messages were widely discussed in the Albanian communist leadership for quite some time. The answer came to them in the VIII Congress of the Labour Party in November 1981, Enver Hoxha had declared that: 'between Albania and the Federal Republic of Germany there are no insurmountable obstacles to establishing diplomatic relations.' ${ }^{13}$ While, in January 1982, in a meeting Communist leader dismissed the next step to not put precondition to establishing diplomatic relations between the two countries. He said: 'Albania and Bonn government wanted to link diplomatic relations, the case of reparations came in the second inning. This problem should be seen as related to diplomatic relations'. ${ }^{14}$

These statements by E.Hoxha, the Congress Party was assessed by the federal government, as a step towards solving the problem of normalizing relations between the two countries and that the attitude of Albania was clear. But the German side asked the Albanian side a formal written statement: where it is not constrained to engage the establishment of diplomatic relations with other issues. This requirement was set as condition for further talks. Ministry of Foreign Affairs of Albania, and he wrote the text was handed government through diplomatic channels FRG. In written and reparations: "you pay and find appropriate ways and forms of payment, which responds to our laws as well as your laws." In response to the German government returned in 1982 marked a step back compared with previous positions. ${ }^{15}$ "The talks stressed that they would be meaningful when the Albanian side would wave the connection with the request for reparations. FRG would not talk about such claims neither before nor after the establishment of diplomatic relations." Albanian government answered the German note. The arrival of the new coalition, headed by German Chancellor Helmut Kohl, initially downplayed the official contact for this matter until the summer of 1983. Meanwhile, this government submitted a request to the government to discuss the problems of war. The German government proposed the development of direct talks in Bonn in April 1984, to the representatives between the two Ministers of Foreign Affairs. Albanian leadership accepted the proposal. Bonn talks marked a step forward in recognizing the clarification of positions on both sides and in presenting the alternatives to overcome the deadlock of negotiations due to the issue of reparations. ${ }^{16}$

The new, during these talks was that the representatives of the Ministry of Foreign Affairs stated German: these relationships would create conditions for economic benefits for the country. In the span of two years that followed, after first meeting in Bonn, three other meetings were developed in Vienna in November 1984, October 1985 and March 1986. There were thrown in two alternatives that would lead to a good solution for both parties concerned. ${ }^{17}$ They gradually created a warm climate of mutual trust, which gave a valuable contribution to the Bavarian Prime Minister Franz Josef Strauss. In mid-1986 it seemed that both sides came close to a final compromise. After resolving issues the two-three pending, in September 1987, in Tirana between representatives of both governments it was signed the protocol for the

\footnotetext{
${ }^{11}$ Bashkurti, Lisen.(2004). The Albanian diplomacy among the past and the future, Tirana, GEER, pg.42-43

12 Smirnova, Nina. mentioned place, pg.409

${ }^{13} \mathrm{AQSH}$, Fond 14,File 77, Year 1982, pg.73

14 The History of the Albanian nation. (2009). Vol.IV. The science Academy, Tirana, Toena, pg.342

15 The History of the Albanian nation. (2009). Vol.IV. The science Academy, Tirana, Toena, pg.343

${ }_{16}$ Same place

${ }^{17}$ Same place, pg.344
} 
establishment of diplomatic relations. This protocol, after its approval by the Government and the German parliament ratification October 2 ,simultaneously became public in city-capitals of the two countries. ${ }^{18}$ Establishment of these relations was to the benefit of both countries, especially Albania. Besides these relationships appeared important the establishing of relations with the United States and England too. U.S. government had shown interest in Albania since the dissolution of the Albanian-Chinese relations. In April 1980, the State Department had made a statement expressing the willingness of the U.S. to establish diplomatic relations with Albania. A number of senators, congressmen tried to visit Albania even President Richard Nixon himself, in July 1982 had asked to come to Tirana, but was rejected by the Albanian government. ${ }^{19}$ After these negative reactions to the Albanian communist regime, Washington took no other attempt in the second half of the 80 -th.

After the death of E.Hoxha State Department intensified back efforts to establish relations with Albania. Despite the willingness shown by the U.S. government, just as it was forced Albanian developments of events in the late 80s and early 90s, specifically in April officially declared desire to restore relations with the United States. The State Department responded immediately. The first official contact Albanian-American became May 1, 1990 between representatives of the two countries. This was an introductory meeting to discuss the procedures that would be followed to restore diplomatic relations. Those who had hastily placing these relations were the Albanian government. They asked that talks would begin later in May. Impatience of the Albanian Communist authorities, the State Department responded on July 20 with a clear message: "July 2 events in Tirana worried the U.S. about the situation in Albania which has slowed the internal consultations on the issue of relations."20

In Albania, in the framework of the reforms undertaken by the government in May 7, a number of changes to the Criminal Code which were made. "The escape no longer was qualified as a crime against the state, but as illegal border crossing." After these changes in legislation and simplifying procedures for obtaining passports, many young people were encouraged to leave Albania. ${ }^{21}$ In the first days of July, about 6,000 youngsters entered the embassies of foreign countries, seeking political asylum. 'The crisis of the migrants' of July 1990 was the biggest shock in the life of the Albanian society. ${ }^{22}$ According to the U.S., police clashes and attacks on innocent citizens in the path of the embassies of the United States government had done, that he saw suspicious attitude towards the issue of the regime of freedoms and human rights.

On May 11, 1990, UN Secretary General Javier Perez de Cuellar visited Albania. He stated that :without dismantling the system of violence, without drastically improving the status of respect for human rights, Albania could not hope to participate in international organizations. ${ }^{23}$

A second meeting between the two sides took place on August 23. The U.S. diplomat had delivered Albania, a project memorandum understanding between the two governments, to restore diplomatic relations, with five articles and other financial matters of the real ones. The Government's response returned in September, once again showing its readiness, for restoration of these relations.U.S. administration demanded that the Albanian government would implement the commitments that had taken over after the CSCE membership as an observer. ${ }^{24}$

As a result of tremendous international pressure to improve human rights and freedom of conscience and the exercise of faith, Tirana official declined to sign the Helsinki Charter. Consequently, they accepted freedom of religion. Albania was liberated from the notorious name the only atheist state in the world. It was also recognized freedom of speech and press. ${ }^{25}$ December 1990: political pluralism was declared, there was created before the opposition parties with the old regime, was recognized fundamental freedoms and human rights . Only after these legal changes, the U.S. threw the final step: on March 15, 1991 was signed in Washington "Memorandum of Understanding between the Albanian government and American government to restore diplomatic relations."26

This event marked the beginning of a new era in the political arena of our country's international relations after the Cold War. The restoration of these important relationships displayed, because politically it warned radical democratic changes. Also, at the end of the Cold War and the destruction of the Yugoslav Federation light came back on the national

\footnotetext{
18 Same place

19 Same place, pg.333

20 The History of the Albanian nation. (2009). Vol.IV. The science Academy, Tirana, Toena, pg.331

21 Dervishi, Kastriot .(2006). The history of the Albanian state 1912-2005, Tirana ,55, pg.782

22 Same place, 784

${ }^{23}$ Smirnova, Nina.( 2004). The history of Albania during 20 Cent .Tirana, Ideart, pg.416

24 The History of the Albanian nation. (2009). Vol.IV. The science Academy, Tirana, Toena, pg.333

${ }^{25}$ Duka, Valentina.(2007). The History of the Albania 1912-2000, Tirana, Kristalina-KH, pg. 315

26 The History of the Albanian nation. mentioned place, pg.339
} 
issue, but it was important for the Albanian living abroad and who understood that the end of communism in Albania was real. ${ }^{27}$ Almost at the same time was also restored the relations with Great Britain. These relationships were held hostage by: solving the issue of Albanian monetary gold trapped in the London bank and British claims for damages set by the International Court of Justice for human losses as well as damage to British ships in the Corfu Channel incident. Attempts to solve these problems and first contacts with England had begun in 1979. Albanian government reactivates the issue of monetary gold Albanian defined as a solution to the economic situation, after breaking relations with China.

Despite attempts by both parties to resolve these outstanding issues from the past, in the period 1979-1982 appeared vain results. There was a restoration of contacts between the two sides in 1984. Shadows and inherited problems become more apparent over time, instead of diminishing .During this time, there were also exchanges of letters between the two countries, a series of talks ended in 1985. The Albanian communist government was still hostage to old prejudices. By the autumn of 1987 there were further talks with the British government and restore the normalization of diplomatic relations. ${ }^{28}$ Only after R.Alia statements, in tenth plenum in April 1990, the issue of gold and the normalization of relations Albanian-English returned to the attention of both parties.

British reacted immediately, repeating the offer made ten years ago in 1980, to restore bilateral relations without preconditions. They requested formal negotiations with the government to establish diplomatic relations with Albania, without preconditions were established as the FRG. London had given a clear message to Tirana, Albania's membership in the CSCE and the establishment of diplomatic relations with TPE definitely seeks consensus from English government. Talks resumed again, this time after diplomatic contacts. In the first months of 1991 was reached on a joint decision, according to which :at first was declared the restoration of diplomatic relations between the two countries and then held another meeting for full and final resolution of outstanding issues. On 29 May 1991, it was announced the restoration of diplomatic relations between Albania and the United Kingdom.

In conclusion, it seems clear that diplomacy early years' 80 almost non-existent; it was totally dogmatic and led by the Marxist-Leninist doctrine. With the death of E.Hoxha and the arrival of R.Alia ,this diplomacy began to detach somewhat from the old principles and in the mid-80s the first signs emerged of a more active foreign policy, especially in the Balkan tables. But, after major changes at the beginning of the 90s our country will change and foreign policy course. On the basis of this course, diplomacy was oriented towards western countries, trying to solve the problems inherited from the past.

\section{References}

The Central Archives of the Republic of Albania (AQSH):

Fond no.14/AP OU, Year 1982, File.77

Fond no.14/AP OU, Year 1988, File. 4,37

Bashkurti, Lisen.(2004). The Albanian diplomacy among the past and the future,Geer,Tirana.

Bashkurti, Lisen.(2004). Self-Isolation diplomacy, Geer, Tirana.

Dervishi, Kastriot.(2006). The history of the Albanian state 1912-2005, 55 , Tirana.

Demi, Leonard.(2008). Albania and the American Diplomacy, Gutenberg, Tirana.

Duka, Valentina.(2007). The History of the Albania 1912-2000, Kristalina-KH,Tirana.

The History of the Albanian nation.(2009).Vol.IV. The science Academy,Toena,Tirana.

Smirnova, Nina.(2004). The history of Albania during the 20 Cent, Ideart, Tirana.

${ }^{27}$ Demi, Leonard.(2008).Albania and the American Diplomacy, Tirana, Gutenberg, pg.89-90

${ }^{28}$ Same place, pg.342 